\title{
Article \\ The Effect of Artificial Rearing on Live Weight Gain and Bone Morphology of the Tibia in Lambs Prior to Weaning
}

\author{
Michaela J. Gibson ${ }^{1,2} * \mathbb{D}$, Chris W. Rogers ${ }^{1,2} \mathbb{D}$, Emma J. Pettigrew ${ }^{2}$, Sarah J. Pain ${ }^{2}$, Keren E. Dittmer ${ }^{1} \mathbb{D}$, \\ Hitihamy M. G. P. Herath ${ }^{2,3}$ and Penny J. Back ${ }^{1,2}$
}

1 School of Veterinary Sciences, Massey University, Private Bag 11-222, Palmerston North 4442, New Zealand; C.W.Rogers@massey.ac.nz (C.W.R.); K.E.Dittmer@massey.ac.nz (K.E.D.); P.J.Back@massey.ac.nz (P.J.B.)

2 School of Agriculture and Environment, Massey University, Private Bag 11-222, Palmerston North 4442, New Zealand; E.Pettigrew@massey.ac.nz (E.J.P.); S.J.pain@massey.ac.nz (S.J.P.); G.Herath@massey.ac.nz (H.M.G.P.H.)

3 Department of Livestock Production, Faculty of Agricultural Sciences, Sabaragamuwa University of Sri Lanka, Belihuloya 70140, Sri Lanka

* Correspondence: M.gibson@massey.ac.nz

check for updates

Citation: Gibson, M.J.; Rogers, C.W.; Pettigrew, E.J.; Pain, S.J.; Dittmer, K.E.; Herath, H.M.G.P.; Back, P.J. The Effect of Artificial Rearing on Live Weight Gain and Bone Morphology of the Tibia in Lambs Prior to

Weaning. Ruminants 2022, 2, 101-111. https://doi.org/10.3390/

ruminants2010006

Academic Editor: Brian J. Leury

Received: 8 November 2021

Accepted: 12 January 2022

Published: 17 January 2022

Publisher's Note: MDPI stays neutral with regard to jurisdictional claims in published maps and institutional affiliations.

Copyright: (C) 2022 by the authors. Licensee MDPI, Basel, Switzerland. This article is an open access article distributed under the terms and conditions of the Creative Commons Attribution (CC BY) license (https:// creativecommons.org/licenses/by/ $4.0 /)$.

\begin{abstract}
Growth rates associated with different artificial rearing systems have been thoroughly examined in many species. However, the effect of different rearing systems on bone morphology has not been described. The objective of this study was to examine differences in the bone mass and the relationship of peripheral quantitative computed tomography (pQCT) measures of bone with muscle area of ewe-reared lambs and artificially reared lambs. Lambs were opportunistically collected from a concurrent trial examining changes in ewe mammary glands during lactation. Thirteen lambs were artificially reared while the remaining nine were left on their dam. Measures of stature were taken throughout the six-week trial period. At approximately six weeks of age, the lambs were euthanized and the tibia was collected and scanned using peripheral quantitative computed tomography. Artificially reared lambs had reduced live weight gain and an altered pattern of stature growth. There was no effect of treatment on bone morphology $(p>0.05)$, but ewe reared lambs had a greater cortical bone content to muscle area ratio than artificially reared lambs ( $0.06 \mathrm{vs}$. 0.15 , respectively). Differences in growth between ewe reared lambs and artificially reared lambs emphasizes the importance of adequate preweaning nutrition for livestock production systems that routinely use artificial rearing systems.
\end{abstract}

Keywords: bone; artificial rearing; tibia; lamb; bone strength; pQCT

\section{Introduction}

The emergence of conditions such as spontaneous humeral fractures in dairy heifers has emphasized the need to look at the effect of nutrition on bone morphology in commercial livestock systems [1]. However, the use of cattle to examine different nutrition effects comes at a high cost for both the acquisition of the animals and the cost of running a trial. The use of orphan lambs provides a cost-effective method and potential model to quantify the effect of pre-weaning nutrition on bone morphology.

Calves raised on their dam have a higher average daily gain than calves that are artificially reared. It is proposed that this difference is due to dam reared calves having the ability to consume ad libitum milk, whereas in artificial systems, the quantity of milk is often capped [2]. In artificial systems, calves reared on milk replacer, and thus lower quantities of milk volume, subsequently consume more concentrate prior to weaning, making them better adapted for the transition to solely whole food at weaning, reducing the effect of the weaning growth check [2]. 
For adequate pre-weaning growth, it is not only the quantity of milk fed that is important, but the quality of the milk. The crude protein to metabolisable energy ratio requirement for a lamb is significantly higher for a lamb at $5 \mathrm{~kg}$ compared with a lamb at $18 \mathrm{~kg}$ (13.1 and $10.9 \mathrm{~g} / \mathrm{MJ}$, respectively) [3]. However, current commercial milk powders have a $\mathrm{CP} / \mathrm{ME}$ ratio of approximately $11.0 \mathrm{~g} / \mathrm{MJ}$, making it poorly suited for early lamb growth and in excess for later stages of lamb growth [3]. By adjusting the ratio of crude protein to metabolizable energy $(\mathrm{CP} / \mathrm{ME})$ to the theoretical requirements of the lamb growth performance can be improved [4]. The effects of a low $\mathrm{CP} / \mathrm{ME}$ ratio can be reduced with the use of pellets with a high $\mathrm{CP} / \mathrm{ME}$ ratio to supplement changes in the lambs' $\mathrm{CP} / \mathrm{ME}$ ratio requirements [5]. If growth is affected by deficits in nutrition early in a lamb's life resulting in a reduced growth rate, it is possible that longitudinal bone growth will be affected. A high protein diet encourages protein deposition rather than fat deposition, demonstrating the importance of adequate protein consumption for ideal body composition during growth [6].

Although a lot of research has been undertaken to examine the effect of artificial rearing on live weight gain, little has been done to look at how differences in diet affects bone morphology. Gibson et al. [7] examined the effects of whole milk volume (5 L vs. $10 \mathrm{~L}$ ) on peripheral quantitative computed tomography (pQCT) derived measures of bone morphology in calves up to six weeks of age and concluded that there was no effect on the bone morphology measurements obtained. However, it was proposed that if there was an effect on bone, it would be associated with developmental programming during growth, and would appear later in the animal's life. Large-scale retrospective studies of the human population have demonstrated the lifelong effect early growth and nutrition has on the ability of bone to respond to future nutritional challenges and the attainment of peak bone mass [8].

Therefore, the objective of this study was to examine differences in bone mass and the relationship of pQCT measures of bone with the muscle area of ewe-reared lambs and artificially reared lambs.

\section{Materials and Methods}

\subsection{Animals}

Lambs were opportunistically collected from a concurrent trial examining changes in ewe mammary glands during lactation. Twenty-two lambs born to twin bearing ewes lambing in the spring of 2020 (August 2020 to October 2020) were selected for the study. As part of the experimental design for the ewe mammary gland trial, 13 of the lambs (six ewes and seven rams) were removed from their dam within $72 \mathrm{~h}$ of birth to reduce lactation draw. These lambs were artificially reared, while the remaining nine (five ewes and four rams) were left on the ewes. Seven sets of twins were included in the trial with five sets being split into each feeding regime, with one lamb artificially reared and one lamb ewe-reared. The selection of lambs removed from the ewes when one twin remained was random. The sample size used and the ability to correct for sex was limited due to the availability of lambs from the source (ewe mammary gland) trial.

\subsection{Animal Management}

\subsubsection{Artificially Reared}

Artificially reared lambs were housed indoors in pens of two. The lamb feeding regime was adapted from Herath, Pain, Kenyon, Blair, and Morel [4] Each day, milk powder for each lamb was mixed in warm water at a 1:4 (w/w) ratio. Lambs were bottle fed five times per day (08:00 a.m., 11:00 a.m., 14:30 p.m., 18:00 p.m., and 21:00 p.m.) for the first two weeks of life and four times per day (08:00 a.m., 11:00 a.m., 14:30 p.m., and 18:00 p.m.) until slaughter. From one week of age lambs were let outside in a paddock for $10 \mathrm{~h}$ per day (08:00 a.m. to 18:00 p.m.) with access to ad libitum pasture. Lambs were fed at 2.1 times their maintenance requirement so as to match Herath, Pain, Kenyon, Blair, and Morel [4], and Herath et al., 2020. Milk volume was altered accordingly on each weigh day (twice 
weekly). The maintenance requirement was calculated as Mem $=0.40 \mathrm{MJ} / \mathrm{kgLW}^{0.75} \mathrm{~d}^{-1}[3]$. Ad libitum cut pasture was supplied daily when the lambs were indoors overnight. The lambs had ad libitum free access to water.

Individual milk intakes were recorded daily. Samples of milk replacer powder and a subsample of milk from the ewes were collected and stored at $-20^{\circ} \mathrm{C}$ until they were required for chemical analysis (Table 1).

Table 1. Chemical composition of milk replacer and average composition of ewes' milk fed to lambs.

\begin{tabular}{lll}
\hline Chemical Composition & Milk Replacer & Ewe Milk \\
\hline Dry Matter, g/kg & 969.8 & 186 \\
Crude protein, g/kg & 262.9 & 295.7 \\
Fat g/kg & 275 & 381.7 \\
Gross energy MJ/kg & 22.73 & 25.9 \\
Metabolisable energy MJ/kg & $21.82^{\mathrm{a}}$ & $24.94^{\mathrm{a}}$ \\
Lactose g/kg & 350.4 & 258 \\
$\mathrm{CP} / \mathrm{ME} \mathrm{g/MJ}$ & $12.05^{\mathrm{b}}$ & $11.86^{\mathrm{b}}$ \\
\hline
\end{tabular}

${ }^{a}$ Calculated as metabolisability $=0.96$ [6]. ${ }^{\mathrm{b}}$ Calculated.

\subsubsection{Ewe Reared}

Ewe reared lambs were reared outside at all times and had unlimited access to their mother and the pasture. A bulk milk sample was taken from a subset of ewes ( 6) each week (six samples in total) and was submitted for analysis on the day of collection (Table 1).

\subsection{Proximate Analysis of Samples}

Milk replacer and the ewes' milk samples were analyzed for crude protein content by the Dumas method (method 968.06 [9]). The fat content of the milk powder and milk protein concentrate were determined by the Mojonnier extraction method (method 989.05, [9]) and the gross energy content by bomb calorimetry.

\subsection{Sampling and Measurement}

Measures of live weight (to the nearest $10 \mathrm{~g}$, Wedderburn, New Zealand), leg length (from ground to olecranon), and wither height were measured using a flexible tape measure to the nearest $0.5 \mathrm{~cm}$ (Korbond, Lincolshire, UK). The thoracic height was calculated by subtracting the leg length from the wither height. These measurements were collected twice a week (Mondays and Thursdays) for the indoor lambs, from birth to euthanasia. Due to the management constraints with the ewe udder trial, the ewe reared lambs were measured at one, two, four, and six weeks of age.

At six weeks of age, indoor and outdoor lambs were humanely euthanized via captive bolt and exsanguination. At time of euthanasia, the entire left hind leg including the fibula was removed, with the muscle and skin intact. The legs were double wrapped in plastic wrap and stored at $-20{ }^{\circ} \mathrm{C}$ until scanning.

\section{5. $p Q C T$}

Peripheral quantitative computed tomography (pQCT) scanning of the intact hind leg was carried out using an XCT 2000 peripheral quantitative computed tomography machine (Stratec Medical, Pforzheim, Germany). For each scan, a $2 \mathrm{~mm}$ slice at the proximal metaphysis, distal metaphysis, and mid-diaphysis was obtained with a voxel size of $0.3 \mathrm{~mm}$. The tibia length was obtained using the distal end of the lateral malleolus to the proximal edge of the tibial tuberosity. The proximal metaphysis was defined as $8.5 \%$ of the total bone length, the distal metaphysis as $20 \%$ of total bone length, and the mid-diaphysis as $50 \%$ of the total bone length, measured from the distal end of the tibia [10]. Within the manufacturer's software, voxels $>710 \mathrm{mg} / \mathrm{cm}^{3}$ calcium hydroxyapatite (CaHA) were assigned as "cortical" bone. Data derived from the scan included measures of the total bone content $\left(>710 \mathrm{mg} / \mathrm{cm}^{3}\right)$, cortical density, total area, cortical area, cortical content, cortical 
density, cortical area, cortical thickness, cortical/subcortical bone area, cortical/subcortical bone density, cortical/subcortical content, trabecular bone area, trabecular bone density, trabecular bone content, periosteal circumference, endosteal circumference, and stressstrain index (SSI). Muscle area was derived from the mid-diaphysis scan as the area between $40-280 \mathrm{mg} / \mathrm{cm}^{3}$.

The stress-strain index is a derived measure of bone strength using pQCT data and avoids the requirement for destructive testing using techniques such as the three-point bending test. The stress-strain index describes the ability of bone to withstand bending from lateral, dorso-palmar, and torsional forces, and is calculated by incorporating the index of material stiffness (bone mineral density) and bone geometry (cross-sectional moment of inertia) [11]. The pQCT variables will be referred to as bone parameters in the statistical models.

\subsection{Statistical Analysis}

Statistical analysis was conducted using SAS version 9.4 (SAS Institute Inc., Cary, NC, USA). Bone parameters were analyzed using general linear models. Models included the fixed effect of treatment (artificially reared or ewe reared) and the covariate of live weight. The interaction of live weight and treatment was tested but was not significant. The effect of sex was also tested but was not significant.

The experiment was carried out at Massey University, Palmerston North, New Zealand, from August 2020 to October 2020, with approval from the Massey University Animal Ethics Committee (MUAEC 20/53).

\section{Results}

Ewe reared lambs grew in a linear manner from birth to six weeks of age. Minimal growth was observed in artificially reared lambs until 25 days of age, where exponential growth was observed (Figure 1).
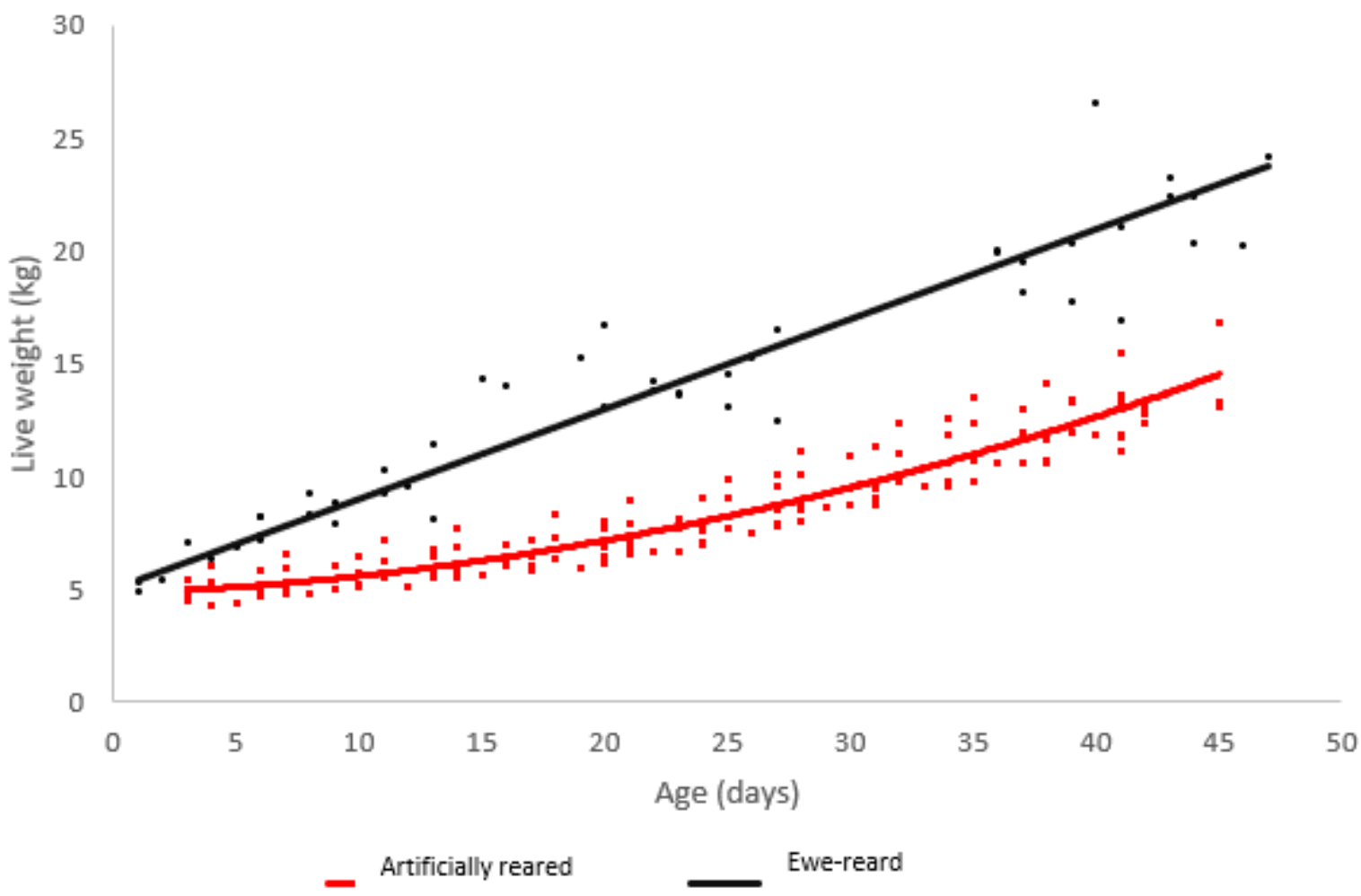

Figure 1. Scatterplot of live weight vs. age for lambs raised artificially (red) and on ewes (black) with regression lines. 
The ewe reared lambs had a greater average daily live weight gain from birth to 6 weeks of age, resulting in a larger live weight at the time of slaughter. There was no effect of treatment on height, but the ewe reared lambs had a longer leg length (Table 2).

Table 2. Unadjusted weights and stature measures for lambs artificially reared and ewe reared at six weeks of age.

\begin{tabular}{llll}
\hline & Artificially Reared & Ewe Reared & $p$-Value \\
\hline$n$ & 13 & 9 & - \\
Birth weight $(\mathrm{kg})$ & $5.2 \pm 0.2$ & $5.3 \pm 0.2$ & 0.907 \\
Average daily gain (kg/day) & $0.22 \pm 0.02$ & $0.38 \pm 0.01$ & $<0.001$ \\
Slaughter weight $(\mathrm{kg})$ & $13.1 \pm 0.5$ & $21.6 \pm 0.6$ & $<0.001$ \\
Age at slaughter (days) & $41.6 \pm 0.6$ & $43.9 \pm 0.7$ & 0.027 \\
Wither height $(\mathrm{cm})$ & $59.0 \pm 0.6$ & $58.8 \pm 0.7$ & 0.852 \\
Leg length $(\mathrm{cm})$ & $32.0 \pm 0.4$ & $34.4 \pm 0.5$ & $<0.001$ \\
Thoracic height $(\mathrm{cm})$ & $27.0 \pm 0.4$ & $24.3 \pm 0.5$ & 0.001 \\
Tibia length $(\mathrm{mm})$ & $146.5 \pm 1.8$ & $149.1 \pm 2.1$ & 0.366 \\
\hline
\end{tabular}

Increases in height and thoracic height in ewe reared lambs followed an expected growth trajectory, with rapid increases in growth followed by a plateau (Figure 2). There was limited growth within the leg length.

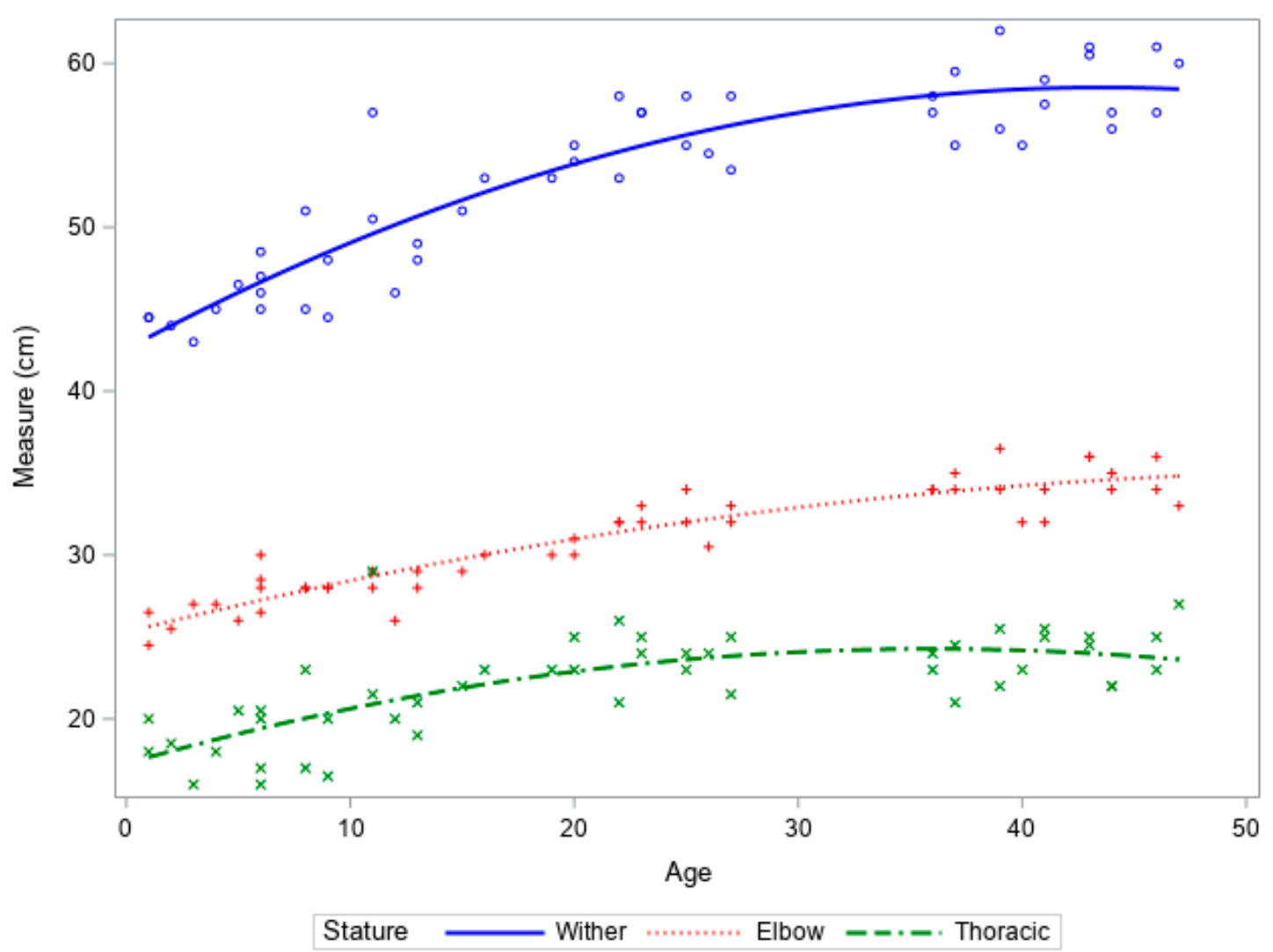

Figure 2. Growth curves of wither height, leg length, and thoracic height vs. age of ewe reared lambs from birth to 6 weeks of age.

Increases in wither and thoracic height were slow until 25 days of age, after which there was an increase in both stature and thoracic measurements (Figure 3). Increases in leg length were limited and reflected the observations in the ewe fed lambs. 


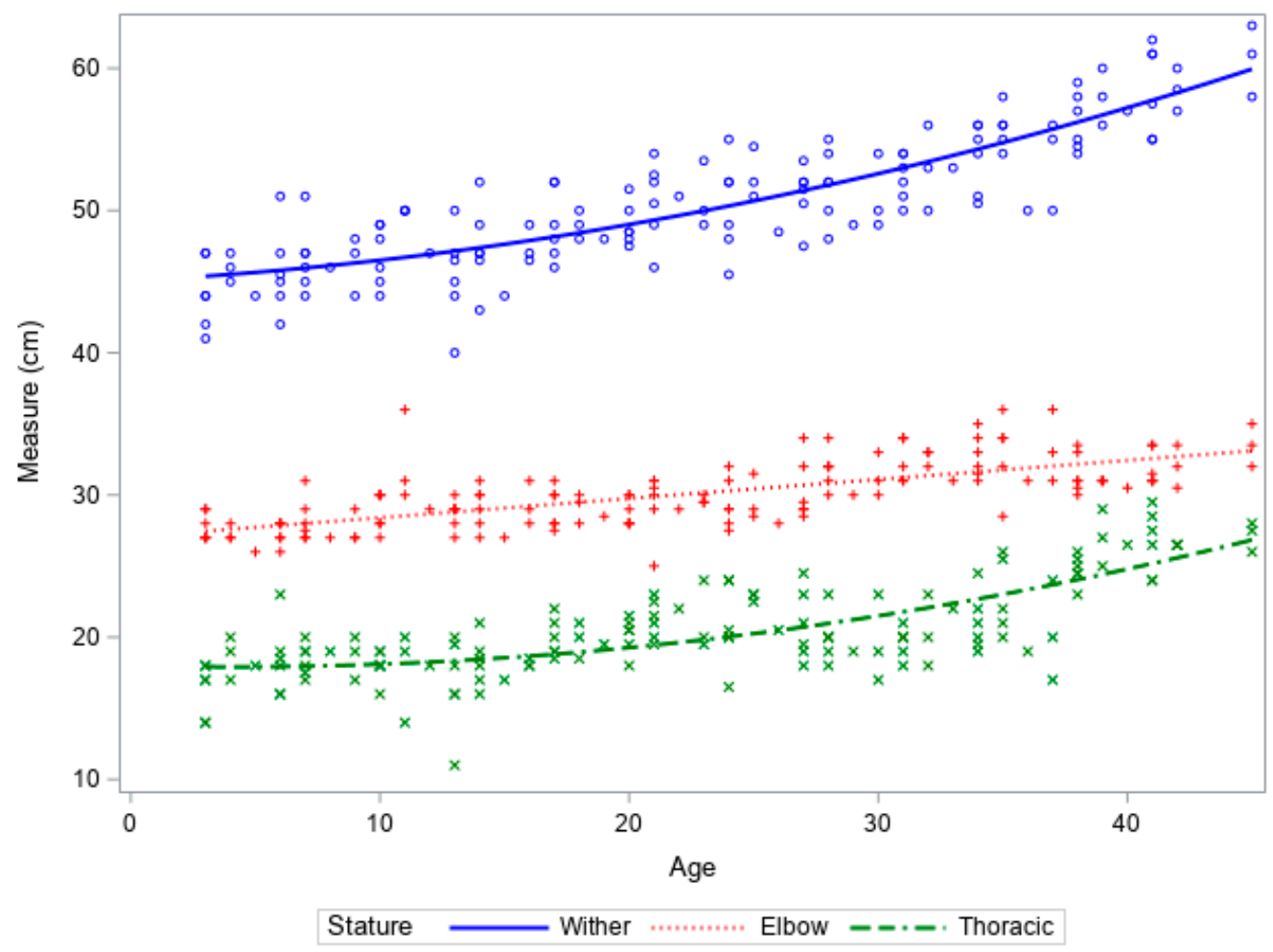

Figure 3. Growth curves of wither height, leg length, and thoracic height vs. age of artificially reared lambs from birth to 6 weeks of age.

When adjusted for live weight, the ewe reared lambs were shorter at the wither than artificially reared lambs at the same live weight but there was no difference in leg length or tibia length (Table 3).

Table 3. Least squares means and standard error of stature measures adjusted for live weight for lambs artificially reared and ewe reared at six weeks of age.

$p$-Value

\begin{tabular}{lllll}
\hline & Artificially Reared & Ewe Reared & Live Weight & Treatment \\
\hline Age (days) & $43.9 \pm 1.0$ & $40.7 \pm 1.4$ & 0.017 & 0.171 \\
Wither height $(\mathrm{cm})$ & $62.1 \pm 0.9$ & $54.3 \pm 1.2$ & $<0.001$ & $<0.001$ \\
Leg length $(\mathrm{cm})$ & $33.9 \pm 0.6$ & $31.7 \pm 0.8$ & 0.009 & 0.102 \\
Thoracic height $(\mathrm{cm})$ & $28.2 \pm 0.8$ & $22.6 \pm 1.1$ & 0.089 & 0.005 \\
Tibia length $(\mathrm{mm})$ & $151.5 \pm 3.2$ & $142.0 \pm 4.4$ & 0.082 & 0.196 \\
\hline
\end{tabular}

The association of live weight with the measurements in the mid-diaphysis reflected the effect of increased live weight on the bending strain of the tibia, such that the live weight was associated with increased values for muscle area, total bone content, and cortical bone content (Table 4). As all lambs had a similar unadjusted tibia length and muscle area, the correction for live weight meant that at similar weights, the ewe reared lambs would have had a smaller muscle area and a greater bone content to muscle area ratio than the artificially reared lambs of the same weight.

In the distal metaphysis, live weight influenced all bone measures except for cortical bone density. The treatment had no effect on the bone measurements in the metaphysis $(p>0.05)$. Live weight influenced some measures in the metaphysis, with a greater live weight associated with a greater total bone area and content, as well as trabecular area, trabecular content, and trabecular density. There was no effect of treatment on any measures in the epiphysis. 
Table 4. Least squares means of the bone parameters of the mid-diaphysis, distal metaphysis, and metaphysis of the tibia of lambs artificially reared and ewes reared at six weeks of age, adjusted for live weight.

\begin{tabular}{|c|c|c|c|c|}
\hline \multirow[b]{2}{*}{ Bone Parameter } & \multirow[b]{2}{*}{ Artificially Reared } & \multirow[b]{2}{*}{ Ewe Reared } & \multicolumn{2}{|c|}{$p$-Value } \\
\hline & & & Live Weight & Treatment \\
\hline \multicolumn{5}{|l|}{ Mid-diaphysis } \\
\hline Muscle area $\left(\mathrm{mm}^{2}\right)$ & $1552.8 \pm 156.3$ & $697.8 \pm 201.0$ & 0.008 & 0.020 \\
\hline Total bone area $\left(\mathrm{mm}^{2}\right)$ & $146.6 \pm 8.5$ & $135.0 \pm 11.7$ & 0.127 & 0.546 \\
\hline Total bone content $(\mathrm{m} / \mathrm{mm})$ & $120.9 \pm 8.5$ & $98.6 \pm 11.7$ & 0.034 & 0.253 \\
\hline Cortical bone thickness (mm) & $3.4 \pm 0.2$ & $3.0 \pm 0.3$ & 0.065 & 0.304 \\
\hline Cortical bone area $\left(\mathrm{mm}^{2}\right)$ & $110.3 \pm 7.5$ & $93.9 \pm 10.3$ & 0.062 & 0.062 \\
\hline Cortical bone content $(\mathrm{mg} / \mathrm{mm})$ & $118.4 \pm 8.4$ & $97.1 \pm 11.6$ & 0.037 & 0.271 \\
\hline Cortical bone density $\left(\mathrm{mg} / \mathrm{mm}^{3}\right)$ & $1070.8 \pm 14.2$ & $1035.8 \pm 19.6$ & 0.056 & 0.284 \\
\hline Stress-strain index $\left(\mathrm{mm}^{3}\right)$ & $335.3 \pm 39.4$ & $266.0 \pm 54.4$ & 0.174 & 0.441 \\
\hline Total bone mineral content: Muscle area ratio & $0.06 \pm 0.01$ & $0.15 \pm 0.02$ & 0.009 & 0.005 \\
\hline Cortical bone content: Muscle area ratio & $0.06 \pm 0.01$ & $0.15 \pm 0.02$ & 0.010 & 0.005 \\
\hline \multicolumn{5}{|l|}{ Distal metaphysis } \\
\hline Total bone area $\left(\mathrm{mm}^{2}\right)$ & $215.6 \pm 13.4$ & $178.4 \pm 18.5$ & 0.020 & 0.229 \\
\hline Total bone content $(\mathrm{m} / \mathrm{mm})$ & $112.4 \pm 6.8$ & $92.7 \pm 9.4$ & 0.018 & 0.209 \\
\hline Cortical bone thickness (mm) & $2.5 \pm 0.1$ & $2.3 \pm 0.2$ & 0.163 & 0.404 \\
\hline Cortical bone area $\left(\mathrm{mm}^{2}\right)$ & $111.3 \pm 5.8$ & $91.7 \pm 8.0$ & 0.011 & 0.147 \\
\hline Cortical bone content $(\mathrm{mg} / \mathrm{mm})$ & $107.7 \pm 6.6$ & $89.3 \pm 9.1$ & 0.023 & 0.228 \\
\hline Cortical bone density $\left(\mathrm{mg} / \mathrm{mm}^{3}\right)$ & $966.1 \pm 15.3$ & $970.5 \pm 21.1$ & 0.750 & 0.899 \\
\hline Stress-strain index $\left(\mathrm{mm}^{3}\right)$ & $480.3 \pm 46.7$ & $365.8 \pm 64.5$ & 0.028 & 0.286 \\
\hline \multicolumn{5}{|l|}{ Metaphysis } \\
\hline Total bone area $\left(\mathrm{mm}^{2}\right)$ & $706.2 \pm 46.6$ & $561.3 \pm 64.3$ & 0.011 & 0.180 \\
\hline Total bone content (mg/mm) & $228.3 \pm 19.0$ & $206.9 \pm 26.3$ & 0.058 & 0.621 \\
\hline Cortical/subcortical bone area $\left(\mathrm{mm}^{2}\right)$ & $196.5 \pm 32.4$ & $223.2 \pm 44.8$ & 0.497 & 0.717 \\
\hline Cortical/subcortical bone content $(\mathrm{mg} / \mathrm{mm})$ & $101.5 \pm 22.5$ & $131.0 \pm 31.0$ & 0.783 & 0.564 \\
\hline Cortical/subcortical bone density $\left(\mathrm{mg} / \mathrm{mm}^{3}\right)$ & $512.6 \pm 25.9$ & $570.0 \pm 35.7$ & 0.435 & 0.333 \\
\hline Trabecular bone area $\left(\mathrm{mm}^{2}\right)$ & $509.7 \pm 49.1$ & $338.1 \pm 67.7$ & 0.040 & 0.134 \\
\hline Trabecular bone content (mg/mm) & $126.8 \pm 13.8$ & $76.0 \pm 19.1$ & 0.031 & 0.116 \\
\hline Trabecular bone density $\left(\mathrm{mg} / \mathrm{mm}^{3}\right)$ & $250.8 \pm 13.7$ & $225.4 \pm 18.9$ & 0.302 & 0.415 \\
\hline
\end{tabular}

\section{Discussion}

The average live weight for ewe reared lambs was greater than for artificially reared lambs at the age of slaughter. Despite significantly lower live weights at slaughter, the artificially reared lambs were of a similar stature, due to their greater thoracic height. Based on the live weight measurements, the ewe reared lambs had a linear increase in live weight, whereas the artificially reared lambs that had a sustained early growth check failed to achieve adequate compensatory growth to match the slaughter weight of the ewe reared lambs. Two probable causes for this may be the mismatch in the $\mathrm{CP} / \mathrm{ME}$ ratio associated with milk replacer during the initial periods of pre-weaning growth and limited intake in comparison to lambs suckling from their dam and consuming ewe's milk ad libitum.

Restricted live weight gain and lighter weaning weights have been reported in artificially reared calves fed $8 \mathrm{~L}$ of whole milk than for calves raised on their dam until weaning. It has been proposed that the differences were due to the restricted feed volumes of the artificially reared calves, whereas calves raised on their dam had unlimited access and were assumed to have consumed approximately $15 \mathrm{~L}$ per day [2]. It is therefore possible that there was an opportunity for greater milk consumption in ewe reared lambs than in the artificially reared lambs. Data from ewe lactation curves indicate that at peak lactation between 7-42 days, a Romney type ewe could yield up to $2.3 \mathrm{~L}$ in milk per day $[12,13]$, well in excess of the $\sim 1.3 \mathrm{~kg}$ /day provided to the artificially reared lambs. 
Even when fed as isometrically balanced diets, differences in milk composition between whole milk and milk replacer result in a greater growth rate for calves artificially reared on whole milk. When the milk replacer composition was adjusted to have a similar gross composition to whole milk, calves on milk replacer still grew slower than calves fed whole milk. The differences in growth rates are thought to be due to a greater bioavailability of nutrients and the presence of growth factors in whole milk that are currently unknown [14].

Milk replacer diets have a constant percentage of protein per $\mathrm{kg}$, unlike ewe milk, in which the percentage of protein increases through lactation [4,15]. In the early stages of growth, lambs require a higher crude protein to $\mathrm{ME}$ ratio than later stages of growth (13.1 vs. $10.9 \mathrm{~g} / \mathrm{MJ}$, respectively) [3]. Therefore, milk replacer for the artificially reared lambs may have failed to provide an adequate $\mathrm{CP} / \mathrm{ME}$ ratio for lambs in early growth stages. The current study had a CP/ME ratio of 12.05 , making it insufficient for early-stage lamb growth, as reflected by the slow growth until $25 \mathrm{~kg}$. The feeding of the artificially reared lambs at $2.1 \times$ maintenance requirements should, in part, have compensated for the lower $\mathrm{CP} / \mathrm{ME}$ ratio, but this still may not have been sufficient to meet the minimum protein requirements for early growth. Theoretically, ewe's milk also has an inadequate $\mathrm{CP} / \mathrm{ME}$ ratio for lambs during the early stages of growth, but in our study, this appeared to be compensated for by the ability for lambs to consume more milk to supplement the lack of protein. This ad libitum or unrestricted milk supply may have permitted the linear growth trajectory observed.

When unadjusted for live weight, artificially reared lambs were the same height as ewe reared lambs but had a shorter leg length and taller thoracic height. The distal limb weight only contributes a small percentage to a lamb's body weight, and thus the differences in live weight must be due to differences in thoracic size and shape. The growth of the ewe reared lambs tended to follow the expected asymptote growth trajectory in the thoracic region, reflecting the same pattern observed in the live weight gain. In contrast, artificially reared lambs had an abnormal growth pattern, where growth in the thoracic region was initially slow or restricted until approximately 25 days of age. This pattern of growth was also reflected in the live weight gain of the artificially reared lambs. The differences in the final live weight reflected that the artificially reared lambs failed to have adequate compensatory live weight gain and associated increases in thoracic capacity to catch up to ewe reared lambs by six weeks of age.

When adjusted for live weight, the artificially reared lambs were taller than the ewe reared lambs but had the same leg length. The growth pattern of the leg length did not appear to be affected by differences in diet, which reflects the limited longitudinal growth potential in the distal limb. Therefore, differences in thoracic shape must account for the differences in height for lambs when adjusted to the same weight. When adjusted for live weight, the ewe reared lambs would be shorter in height but would be wider than the artificially reared lambs, indicating that the growth potential is allocated more to increases in capacity rather than longitudinal bone growth when adequate protein is supplied. The ewe reared lambs had a linear growth trajectory, indicating that they were growing in an uninhibited manner. However, in artificially reared lambs, it is possible that the lack of protein promoted longitudinal growth without concurrent increases in capacity, as well as associated increases in live weight. This pattern of height without concurrent increases in capacity has been described in cattle models, where the inhibition of growth can cause a compensatory increase in height after the growth check is removed, resulting in a greater height than contemporaries without a growth check [16].

A limitation of the current research was that measures of capacity (girth) were not taken. It has been reported that measures of girth are strongly correlated with live weight [7]. Although thoracic height provides an indication of the size of the axial skeleton, the girth would have provided information on the width of the animal and the distribution of live weight when coupled with measures of leg length and height. In addition, the frequency of measurements from ewe reared lambs were less than artificially reared lambs due to 
fewer occasions when the ewes and lambs were in the yards for observation during the mammary gland trial.

The lack of difference in bone morphology between treatments was similar to observations reported in calves, where alterations in milk intake were not associated with pQCT derived measures of bone morphology [7]. Pre-weaning growth in mammals is rapid and highly conserved, greatly limiting differences in the functional morphology. However, inadequate nutrition pre-weaning can have an impact on developmental programming and how bone responds to subsequent nutritional and environmental challenges [17]. Human studies have supported this hypothesis, where the effect of early milk intake can affect future growth by altering the way the bone responds to future challenges such as undernutrition [8]. It is possible that changes in bone as a result of a pre-weaning diet would become more pronounced in later life [17]. Therefore, it is possible that by observing lambs for a longer period and placing a challenge such as a growth check on the lambs, the effect of preweaning diet may have become more pronounced.

Growth in the distal limb bones such as the metacarpus is limited after birth [18], and was reflected in the limited increases in longitudinal length (leg length) relative to increases in wither height. The tibia also demonstrates a limited growth potential compared to the proximal limb, and may explain why there were limited treatment differences between ewe reared and artificially reared lambs. Live weight was associated with many of the measures of bone morphology (bone area and measures of cortical area and content) in the mid diaphysis. Possibly reflecting that the lamb is not a cursorial animal and the early cessation of growth in the tibia meant the stress-strain index was not associated with live weight or treatment.

The use of the tibia for pQCT scanning rather than the humerus (some muscles surrounding the humerus are attached to the axial skeleton, so are not accessible with the muscle intact) [19], permitted estimation of the muscle area, and the bone/muscle ratio at the mid-diaphyseal site. Greater live weight was associated with an increased BMC/muscle ratio, reflecting the greater strain the larger body mass places on the tibia and the load exerted by the flexors and extensors of the tibia. When adjusted for live weight, there was a treatment effect, such that artificially reared lambs had a lower BMC/ muscle ratio. This was unexpected and indicates that the nutritional challenge with an artificial rearing system was associated with a limited, or inhibited ability, for deposition of equivalent BMC relevant to bone strain. In humans, inhibited deposition of BMC due to nutrition restriction (i.e., anorexia) results in a decrease in bone mineral acquisition, which persists later in life [20]. The effect of nutrition on bone is most dramatic during periods of rapid bone growth [21]. However, the long-term effects on bone can be minimized if the nutritional deficit is overcome, but the affected bone will often fail to reach the developmental potential and completely recover increasing the risk of osteoporotic bone fractures in later life [22].

\section{Conclusions}

The milk replacer diet, even at twice estimated maintenance requirements, resulted in a reduced live weight gain and alteration in the pattern of stature growth. Growth in the distal limb was not affected by diet, but differences in thoracic height indicate compensatory growth in the thorax and axial skeleton. The lower $\mathrm{CP} / \mathrm{ME}$ ratio and milk intake coupled with differences in milk composition in the artificially reared lambs may be associated with the initial growth check and the resultant pattern of growth. This pattern of growth is similar to the starvation model seen in other species, where growth checks pre-weaning alter the growth and production potential in later life. This data demonstrates the importance of adequate pre-weaning nutrition in livestock production systems that routinely use artificial rearing and milk replacer to rear stock. 


\begin{abstract}
Author Contributions: Conceptualization, P.J.B. and C.W.R.; methodology, P.J.B., C.W.R., M.J.G. and H.M.G.P.H.; formal analysis, M.J.G.; investigation, M.J.G., P.J.B. and E.J.P.; data curation, E.J.P. and M.J.G.; writing—original draft preparation, M.J.G.; writing—review and editing, M.J.G., C.W.R., S.J.P., H.M.G.P.H., E.J.P., K.E.D. and P.J.B. visualization, C.W.R. and P.J.B.; supervision, P.J.B.; project administration, P.J.B. and E.J.P. All authors have read and agreed to the published version of the manuscript.
\end{abstract}

Funding: This research received no external funding.

Institutional Review Board Statement: The experiment was carried out at Massey University, Palmerston North, New Zealand from August 2020 to October 2020, with approval from the Massey University Animal Ethics Committee (MUAEC 20/53).

Informed Consent Statement: Not applicable.

Data Availability Statement: Data will be available from the first author upon request.

Acknowledgments: The authors would like to thank the Massey University technical staff for their assistance in collecting samples.

Conflicts of Interest: The authors declare no real or perceived conflicts of interest.

\title{
References
}

1. Gibson, M.; Dittmer, K.; Hickson, R.; Back, P.; Wehrle-Martinez, A.; Rogers, C. The Mid-Diaphysis Is a Poor Predictor of Humeral Fracture Risk Indicating That Predisposing Factors Are Recent. Ruminants 2021, 1, 23-30. [CrossRef]

2. Roth, B.A.; Barth, K.; Gygax, L.; Hillmann, E. Influence of artificial vs. mother-bonded rearing on sucking behaviour, health and weight gain in calves. Appl. Anim. Behav. Sci. 2009, 119, 143-150. [CrossRef]

3. Danso, A.S.; Morel, P.C.H.; Kenyon, P.R.; Blair, H.T. Effect of different feeding regimens on energy and protein utilization and partitioning for maintenance and growth in pre-weaned lambs reared artificially1. J. Anim. Sci. 2016, 94, 5359-5371. [CrossRef] [PubMed]

4. Herath, H.; Pain, S.; Kenyon, P.; Blair, H.; Morel, P. Effect of dietary protein to energy ratio of milk replacer on growth and body composition of pre-weaned lambs reared artificially. Anim. Feed. Sci. Technol. 2020, 264, 114478. [CrossRef]

5. Herath, H.; Pain, S.; Kenyon, P.; Blair, H.; Morel, P. Effect of dietary protein to energy ratio on growth performance of pre-and post-weaned lambs. Anim. Feed. Sci. Technol. 2021, 272, 114787. [CrossRef]

6. Danso, A.; Morel, P.; Kenyon, P.; Blair, H. Effects of dietary protein and energy intake on growth, body composition and nutrient utilisation in lambs reared artificially with milk replacers and pellet feeds. Anim. Feed. Sci. Technol. 2018, 237, 35-45. [CrossRef]

7. Gibson, M.; Dittmer, K.; Hickson, R.; Back, P.; Rogers, C. Bone Morphology and Strength in the Mid-Diaphysis of the Humerus and Metacarpus in Dairy Calves Prior to Weaning. Animals 2020, 10, 1422. [CrossRef] [PubMed]

8. Cooper, C.; Cawley, M.; Bhalla, A.; Egger, P.; Ring, F.; Morton, L.; Barker, D. Childhood growth, physical activity, and peak bone mass in women. J. Bone Miner. Res. 2009, 10, 940-947. [CrossRef]

9. AOAC. Official Methods of Analysis; AOAC International: Gaitherburg, MD, USA, 2005.

10. Dittmer, K.E.; Firth, E.C.; Thompson, K.G.; Marshall, J.C.; Blair, H.T. Changes in bone structure of Corriedale sheep with inherited rickets: A peripheral quantitative computed tomography assessment. Veter-J. 2011, 187, 369-373. [CrossRef]

11. Ferretti, J. Perspectives of pQCT technology associated to biomechanical studies in skeletal research employing rat models. Bone 1995, 17, S353-S364. [CrossRef]

12. McMillan, W.; McLachlan, S.; Hercus, I. Brief communiction: High milk production in milked sheep grazed in large flocks in New Zealand. In Proceedings of the New Zealand Society of Animal Production 30 June 2014, Napier, New Zealand; Volume 74, pp. 52-54.

13. Geenty, K. Lactation performance, growth, and carcass composition of sheep: I. Milk production, milk composition, and live weights of Romney, Corriedale, Dorset, Romney $\times$ Dorset, and Dorset $\times$ Romney ewes in relation to the growth of their lambs. $N$. Z. J. Agric. Res. 1979, 22, 241-250. [CrossRef]

14. Lee, H.J.; Khan, M.A.; Lee, W.S.; Yang, S.H.; Kim, S.B.; Ki, K.S.; Kim, H.S.; Ha, J.K.; Choi, Y.J. Influence of equalizing the gross composition of milk replacer to that of whole milk on the performance of Holstein calves. J. Anim. Sci. 2009, 87, 1129-1137. [CrossRef]

15. Pavić, V.; Antunac, N.; Mioč, B.; Ivanković, A.; Havranek, J. Influence of stage of lactation on the chemical composition and physical properties of sheep milk. Czech J. Animal Sci. 2002, 47, 80-84.

16. Handcock, R.C.; Jenkinson, C.M.C.; Laven, R.; McNaughton, L.R.; Lopez-Villalobos, N.; Back, P.J.; Hickson, R.E. Linear versus seasonal growth of dairy heifers decreased age at puberty but did not affect first lactation milk production. N. Z. J. Agric. Res. 2021, 64, 83-100. [CrossRef]

17. Moallem, U.; Werner, D.; Lehrer, H.; Zachut, M.; Livshitz, L.; Yakoby, S.; Shamay, A. Long-term effects of ad libitum whole milk prior to weaning and prepubertal protein supplementation on skeletal growth rate and first-lactation milk production. J. Dairy Sci. 2010, 93, 2639-2650. [CrossRef] [PubMed] 
18. Guilbert, H.R.; Gregory, P.W. Some Features of Growth and Development of Hereford Cattle. J. Anim. Sci. 1952, 11, 3-16. [CrossRef]

19. Gibson, M.; Hickson, R.; Back, P.; Dittmer, K.; Schreurs, N.; Rogers, C. The Effect of Sex and Age on Bone Morphology and Strength in the Metacarpus and Humerus in Beef-Cross-Dairy Cattle. Animals 2021, 11, 694. [CrossRef] [PubMed]

20. Javaid, M.; Cooper, C. Prenatal and childhood influences on osteoporosis. Best Pract. Res. Clin. Endocrinol. Metab. 2002, 16, 349-367. [CrossRef] [PubMed]

21. Craig, L.; Dittmer, K.; Thompson, K. Bones and Joints. In Pathology of Domestic Animals; Elsevier Health Sciences: Amsterdam, The Netherlands, 2016; Volume 1.

22. Miller, K.K.; Grinspoon, S.K.; Ciampa, J.; Hier, J.; Herzog, D.; Klibanski, A. Medical Findings in Outpatients with Anorexia Nervosa. Arch. Intern. Med. 2005, 165, 561-566. [CrossRef] [PubMed] 